\title{
Correction to: Entrepreneurship capital spillovers at the local level
}

\author{
José Luis Massón-Guerra • Pedro Ortín-Ángel
}

Published online: 26 March 2021

(C) Springer Science+Business Media, LLC, part of Springer Nature 2021

\section{Correction to: Small Bus Econ (2019) 52:175-191 https://doi.org/10.1007/s11187-018-0014-8}

The article "Entrepreneurship capital spillovers at the local level," written by José Luis Massón-Guerra and Pedro Ortín-Ángel was originally published Online First without Open Access. After publication in volume 52, issue 1, pages 175-191, the author decided to opt for Open Choice and to make the article an Open Access publication. Therefore, the copyright of the article has been changed to (C) The Author(s) 2021, and the article is forthwith distributed under the terms of the Creative Commons Attribution 4.0 International License, which permits use, sharing, adaptation, distribution, and reproduction in any medium or format, as long as you give appropriate credit to the original author(s) and the source, provide a link to the Creative Commons licence, and indicate if changes were made. The images or other third party material in this article are included in the article's Creative Commons licence, unless indicated otherwise in a credit line to the material. If material is not included in the article's Creative Commons licence and your intended use is not permitted by statutory regulation or exceeds the permitted use, you will need to obtain permission directly from the copyright holder. To view a copy of this licence, visit http://creativecommons.org/licenses/by/4.0/.

The original article has been corrected

Publisher's note Springer Nature remains neutral with regard to jurisdictional claims in published maps and institutional affiliations.

The online version of the original article can be found at https://doi.org/10.1007/s11187-018-0014-8

J. L. Massón-Guerra $(\bowtie) \cdot P$. Ortín-Ángel

Business Department, Universitat Autònoma de Barcelona,

Barcelona, Spain

e-mail: joseluis.masson@uab.cat 